\title{
Effect of mixing method on the mini-slump spread of Portland cement pastes
}

\section{Efeito do método de mistura sobre o espalhamento mini-slump de pastas de cimento Portland}

\author{
J. S. RAUCCI ab \\ julia.raucci@Ime.pcc.usp.br \\ R. T. CECEL b \\ rafael.cecel@lme.pcc.usp.br \\ R. C. O. ROMANO b \\ rcorjau@gmail.com \\ R. G. PILEGGI \\ rafael.pileggi@lme.pcc.usp.br \\ V. M. JOHN b \\ vmjohn@usp.br
}

\begin{abstract}
The current compressive strength test for cement classification is performed under a fixed water to cement ratio according to the Brazilian and European standards, regardless the consistency obtained. However, under practical conditions the amount of water required is related to the rheological need to obtain and maintain a desired workability. Intrinsic cement characteristics influence the water demand such as the cement particle's granulometry, specific surface area, density, the presence or not of water reducing admixtures, chemical and mineralogical nature of raw materials, etc., influence particles agglomeration state. Because water demand influences the mechanical properties of cement based products, the compressive strength class under a fixed water to solids ratio specified by the standards may not be representative for the user. The present work investigates the influence of mixing conditions on mini-slump spread results, a test that has been used for many years but never standardized. Cement paste samples were produced with varied mixing conditions (time and rotation speed) using a conventional stirrer and subjected to mini-slump spread test immediately after mixing and at fixed hydration times. Results show that mixing and hydration time do influence on minislump spread. At lower rotation speeds, results variability increases. Under fixed time after first contact with water, increasing rotation speed leads in a reduction of results variability and increase the test's repeatability on cement pastes.
\end{abstract}

Keywords: Portland cement, mini-slump spread, mixing.

\section{Resumo}

O ensaio de resistência do cimento, segundo às normas brasileiras e europeia atuais, é realizado com uma relação água/cimento fixa em massa, independente da consistência obtida. No entanto em condições normais de uso, a quantidade de água é uma variável definida com a finalidade de manutenção da consistência dos materiais cimentícios para obter trabalhabilidade adequada. Características intrínsecas dos ligantes, como distribuição de tamanho de partículas, área superficial especifica, densidade e natureza química ou mineralógica, ou extrínsecas, como presença de aditivos, temperatura ambiente e da água, tempo e energia de processamento, etc., podem afetar de forma distinta o estado de aglomeração e, consequentemente, a necessidade de líquido para a mistura. Como a demanda de água influencia a resistência mecânica dos produtos, a utilização da relação água/cimento fixa torna, em termos práticos, a classificação do cimento pela resistência pouco significativa para o usuário. Neste trabalho foi investigada a influência das condições de mistura na repetibilidade do ensaio de mini-slump, bastante usado para avaliação da quantidade de água nas composições, mas não normatizado. Pastas de uma mesma amostra de cimento foram misturadas por diferentes tempos e/ou rotações, usando um agitador mecânico convencional, e submetidas ao ensaio de mini-slump imediatamente após o ensaio ou após o mesmo tempo de contato com a água. Observou-se influência significativa nos resultados: quanto maior a rotação ou a manutenção do tempo de mistura, menor a variabilidade do espalhamento mini-slump sendo que a influência é mais sensível para diferenças de rotação.

Palavras-chave: cimento Portland, mini-slump, mistura. 


\section{Introduction}

Water demand impacts directly on the mechanical strength of cement based products. The water excess increases the amount of capillary pores hence microstructural defects. Still, standardized testing methods to determine compressive strength of cement according to both Brazilian (ABNT, NBR 7215) and European (EN 1971) standards are performed with a fixed water to cement mass ratio. As cement substitution increases by supplementary cementitious materials, which may be very different in terms of chemistry, mineralogical and physical characteristics, the amount of water to obtain the necessary workability in the use of these cements differs just as much. The standardized tests based on a fixed water to cement ratio may not reflect users' perception. In self-consolidating concrete mix design, for instance, water content is adjusted following slump flow tests. Therefore, cements in the same compressive strength class may reflect in very different performances in use.

Testing methods such as flow table, Marsh-cone and Kantro's mini-slump cone are quite simple to run and implement as quality control methods even considering that these methods are not the most recommended for scientific research. Rotational Rheometry, on the other hand, is the type of testing method that demands more practice to run and analyze, but defines water demand based on rheological parameters such as viscosity and yield stress. In addition, it allows an evaluation of cement properties simulating different shear conditions and is a tool to explain the behavior observed on more simple tests or single-point tests.

However, one of the main issues on rheological testing methods is mixing energy. It is a common sense that mixing energy has a huge impact on rheological behavior of cement products hence on water demand as it affects particles dispersion (ROMANO et al., 2009; WILLIAMS; SAAK; JENNINGS, 1999; YANG; JENNINGS,
1995). Regardless of the water content determined by each testing method, sample preparation will always play and important role on the result. Thus, repeatability, reproductivity and efficiency of any testing method for water demand evaluation depends on a suitable mixing method.

This work is the first step of a study to develop a standard minislump testing protocol for cement pastes. Repeatability of results were analyzed as a function of mixing conditions. Also, tests were performed to correlate mini-slump results with Rotational Rheometry and evaluate the impact of mixing conditions in cement hydration by Isothermal Calorimetry.

\section{Background}

Immediately after water is mixed with cement, clusters of particles start to form due to Van Der Waals forces capillary actions (Figure 2.1). As these clusters are randomly formed, they alter the real particle size distribution and water gets trapped in their within which modifies the rheology of the system. Clusters are a source of variability in a consistency testing method. The more homogeneous and dispersed are the cement particles in solution, the lower will be the variability of the following testing method.

Different mixing conditions will create fluids with different rheological behavior. The rheological profile measurement by Rotational Rheometry in cement pastes, mortars or concretes is the most complete method to evaluate the mixture behavior under different types of stresses that they can be subjected to. Under various shear rates a mixture response can be composed by basic rheological profiles (Newtonian, pseudoplastic, dilatant, Bingham etc.) (BANFILL, 2006; PANDOLFELLI et al., 2000). Unfortunately, Rheometers are expensive equipment and proper training is a must for testing and adequate data analysis.

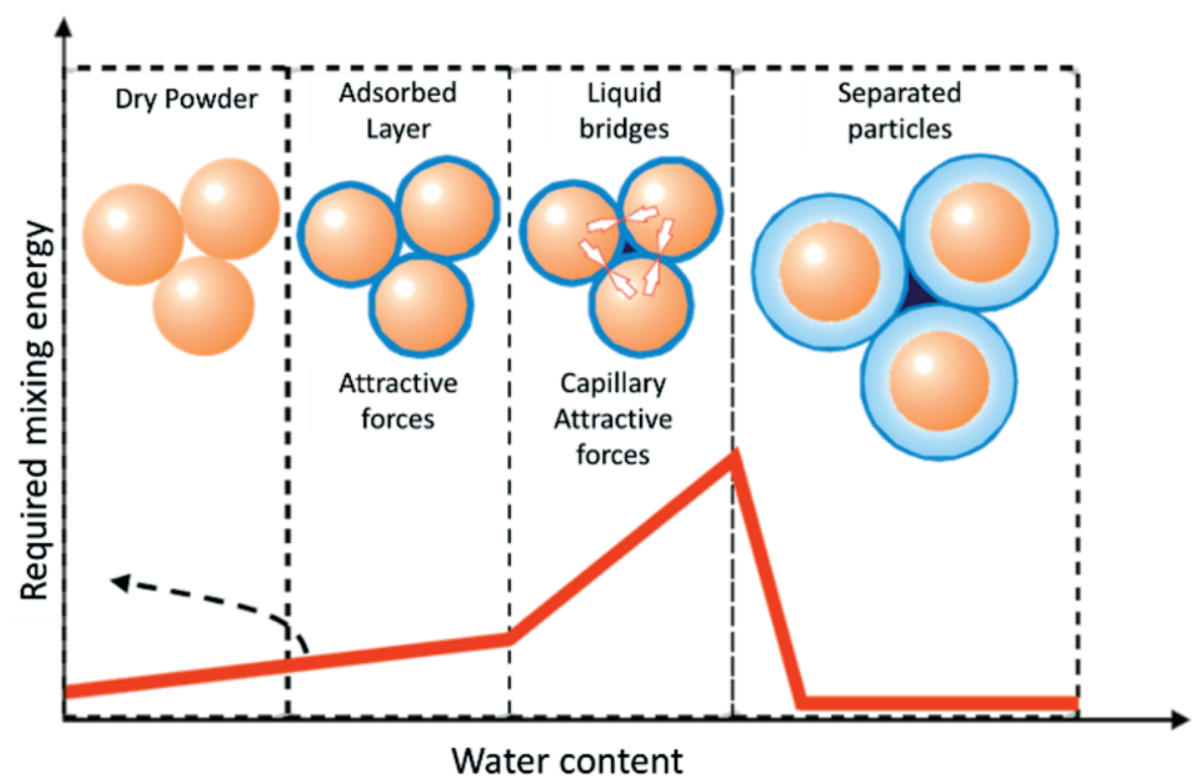

Figure 2.1

Scheme of adsorbed layers and liquid bridges formation between particles in liquid media (PANDOLFELLI et al., 2000) 


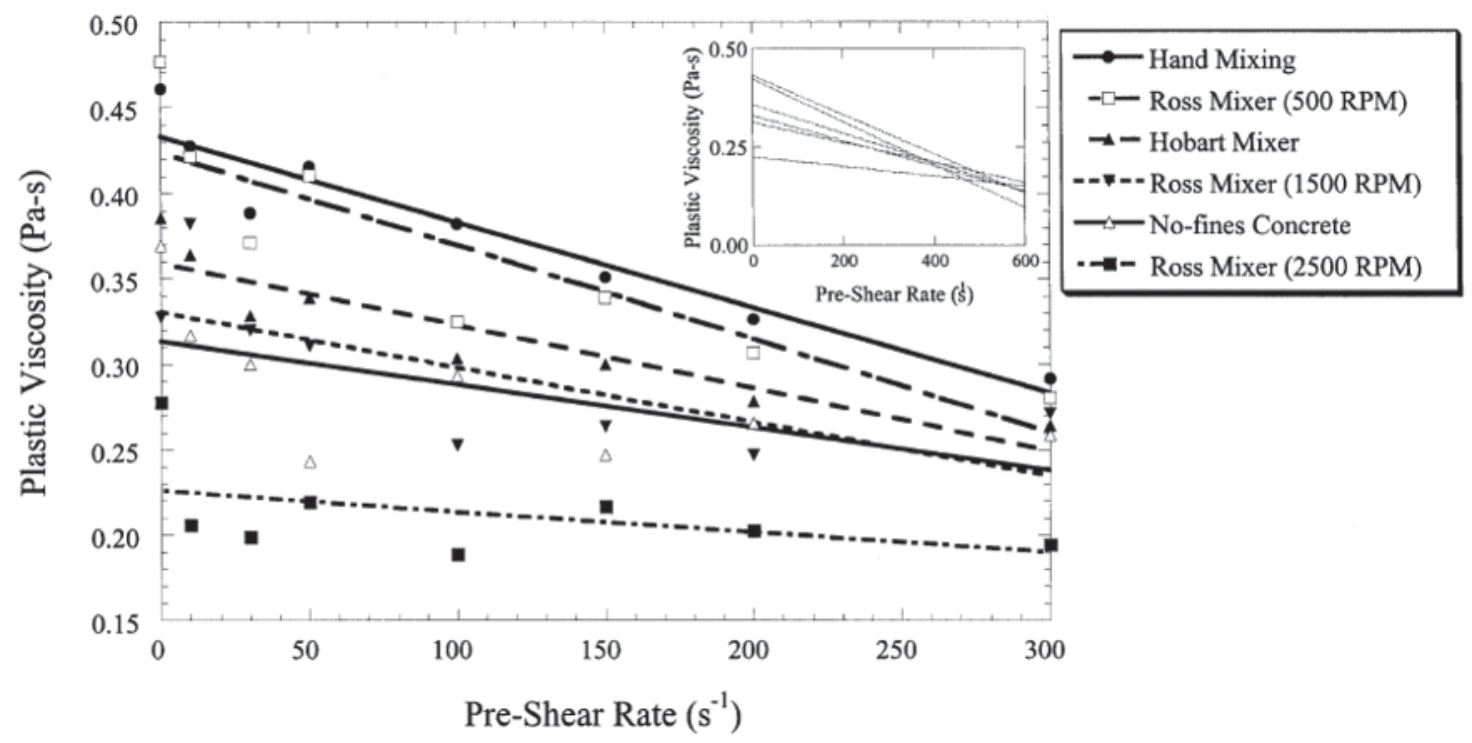

Figure 2.2

Plastic viscosity as a function of pre-shear rate of different mixing methods (WILLIAMS; SAAK; JENNINGS, 1999)

Other simpler techniques for water demand evaluation, even though are considered single point tests (BANFILL, 2006), are relevant in the absence of a more complete testing method. These techniques include the flow table test performed in mortar as an alternative method. The current ASTM standard stands that cements with higher substitution rates should have their water content for strength testing determined by a flow table test (ASTM C109). Because it is conducted in mortar and a large amount of material is used, this test can be overwhelming to be implemented as a process control test, but it is an alternative for water demand estimation as a water content correction as a function of mortar spreading (SANYTSKY; KROPYVNYTSKA; RUSYN, 2015).

The Marsh cone and mini-slump cone are techniques that can be applied in cement paste. It is possible to find many references naming these testing methods as supplementary testing as results can be correlated to rheological parameters. Time to flow, for instance, from the Marsh cone test is related to apparent viscosity when modeled with cement's characteristics. The minislump spread is related to yield stress (BANFILL, 2006; GAO; FOURIE, 2015). These are techniques of fast execution and rapid implementation techniques, yet both need proper mixing methods to be repetitive.

Therefore, a mixing method with enough energy to separate agglomerated particles formed by attractive forces (PANDOLFELLI et al., 2000) are a pre-condition to rheological testing methods of pastes, mortars and concretes. Previous works that evaluated mixing energy effect on rheological behavior showed that the higher the mixing energy, the higher the deagglomeration of particles (WILLIAMS; SAAK; JENNINGS, 1999; YANG; JENNINGS, 1995).

In Figure 2.2 bellow is presented plastic viscosity results measured by Rotational Rheometry in cement pastes subjected to different mixing methods. The results show the smaller plastic viscosity for the higher the mixing energy. In the same study the hysteresis loop area from continuous flow measurements and the results show a bigger hysteresis loop the smaller the energy, which indicates that the not well mixed pastes go through a deagglomeration process during testing (WILLIAMS; SAAK; JENNINGS, 1999). Therefore, testing of pastes from higher mixing energy methods would be more repetitive.

Mixing conditions can also influence the hydration heat hence the microstructure of the hardened paste. Studies show that reaction kinetics increases as mixing energy increases which is due to the higher contact area between the cement grains and water as well as the shock energy and friction between particles (BERODIER; SCRIVENER, 2015; DOLLIMORE; MANGABHAI, 1985; JUILLAND et al., 2012; TAKAHASHI; BIER; WESTPHAL, 2011; YANG; JENNINGS, 1995).

\section{Experimental program}

\subsection{Materials}

Cement pastes were produced from a CEM II/B-L 32,5N (Portlandlimestone cement) according to EN-197 standard and a water to cement ratio of 0,45 . The amount of water was determined by preliminary tests to evaluate the minimum water content necessary for the mini-slump test.

The cement had a BET specific surface area of $2,96 \mathrm{~g} / \mathrm{cm}^{3}$, initial setting time of 335 minutes, Blaine surface area of $6150 \mathrm{~cm}^{2} / \mathrm{g}$ and 75 um fineness of $1,3 \%$. The particle size distribution (measured in a Malvern Mastersizer 2000 in ethanol) is shown in Figure 3.1. Chemical composition (Table 3.1) was obtained following guidelines from Portland composite cements specification from NBR11578:1991 (ABNT, 1991). Mineralogical analysis by semiquantitative XRD (obtained from Rigaku Windmax 1000 and XPert HighScore Plus 4.1 software from Panalytical) is illustrated in Table 3.2. 


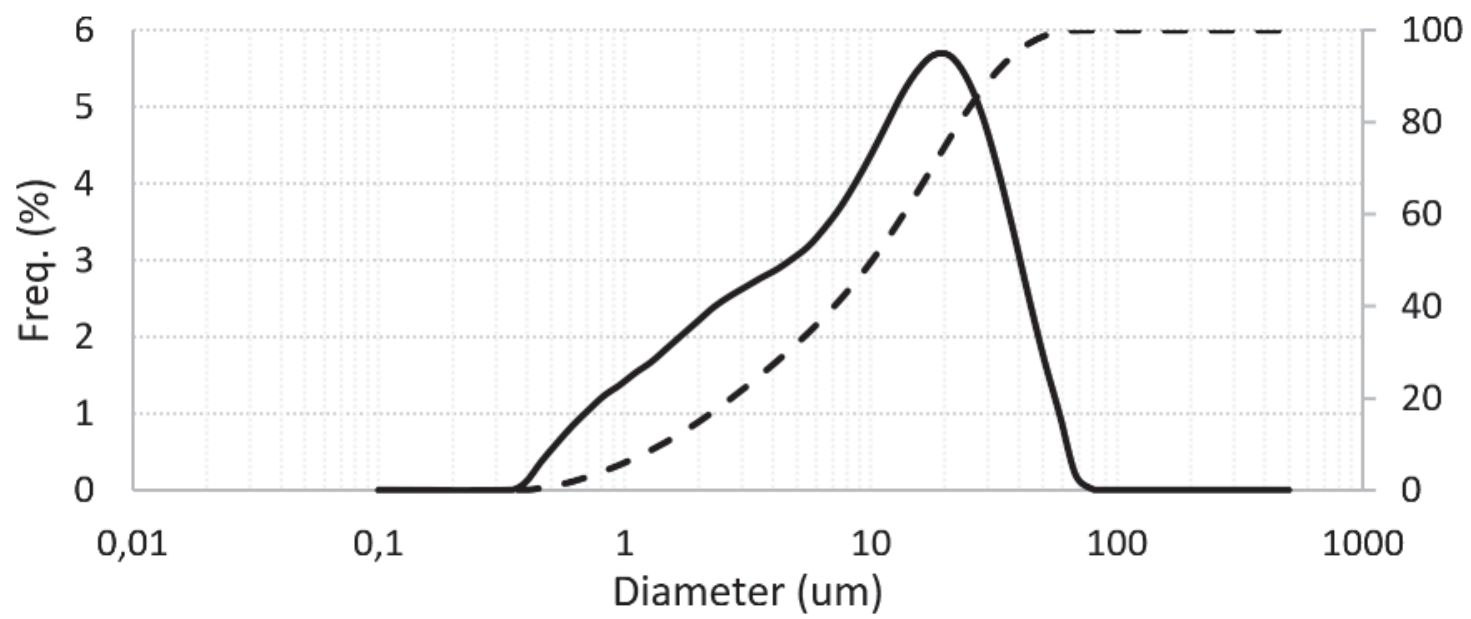

80

Figure 3.1

Cement particle size distribution

Table 3.1

Cement chemical composition (\%)

\begin{tabular}{|c|c|c|c|c|c|c|c|c|c|c|c|}
\hline $\mathbf{P F}$ & $\mathbf{S i O}_{2}$ & $\mathbf{A l}_{2} \mathbf{O}_{3}$ & $\mathrm{Fe}_{2} \mathrm{O}_{3}$ & $\mathbf{C a O}$ & $\mathbf{M g O}$ & $\mathbf{S O}_{3}$ & $\mathbf{N a}_{2} \mathbf{O}$ & $\mathbf{K}_{2} \mathbf{O}$ & $\mathbf{C a O}-\mathbf{I}$ & $\mathbf{R I}$ & $\mathbf{C O}_{2}$ \\
\hline 13,2 & 15,6 & 3,62 & 2,42 & 59,9 & 1,77 & 2,25 & 0,08 & 0,73 & 1,15 & 1,94 & 11,4 \\
\hline
\end{tabular}

\subsection{Methods}

\subsubsection{Mixing conditions}

Cement pastes were mixed in a metallic cocktail shaker using a mechanical stirrer IKA RW20 attacked to a naval helix of $35 \mathrm{~mm}$ diameter. Mixing conditions varied as a function of: mixing time $(60,90,180,210$ to 300 seconds),

rotation speed (320 to $2550 \mathrm{rpm}$ ) and

- time of testing (immediately after mixing or 340 seconds after water contact).

Hydration time was considered as a possible variable; hence some testing was conducted after waiting for all pastes to reach the same time after the first contact with water with 10 seconds of remixing time. A scheme of the mixing plan is presented in Figure 3.2.

\section{Table 3.2}

Semi-quantitative XRD composition (\%)

\begin{tabular}{|c|c|c|c|c|c|c|c|c|c|}
\hline Phase & $\mathbf{C}_{3} \mathbf{S}$ & $\mathbf{C}_{2} \mathbf{S}$ & $\mathbf{C}_{3} \mathbf{A}$ & $\mathbf{C}_{4} \mathbf{A F}$ & Dolomite & Calcite & Bassanite & Anhydrate-II & Quartz \\
\hline \multirow{2}{*}{ PDFs } & $00-013-$ & $01-086-$ & $01-070-$ & $96-900-$ & $01-075-$ & $01-086-$ & $01-083-$ & $01-072-$ & $46-1045$ \\
& 0272 & 0398 & 0839 & 3349 & 1711 & 0174 & 0438 & 0916 & 46 \\
\hline$\%$ & 42,7 & 13,1 & 3,8 & 5,7 & 1,1 & 30,4 & 1,8 & 0,4 & 0,9 \\
\hline
\end{tabular}
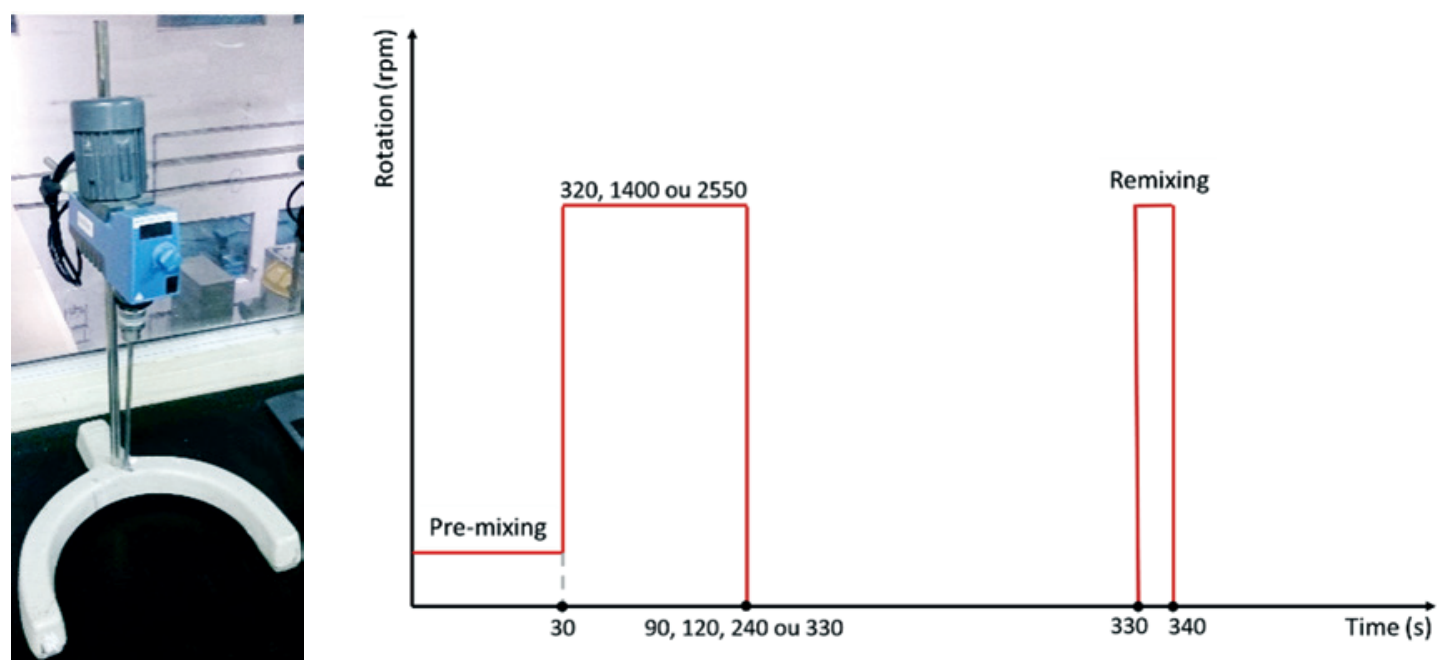

Figure 3.2

Mechanical stirrer IKA RW20 (left) and mixing conditions (right) 


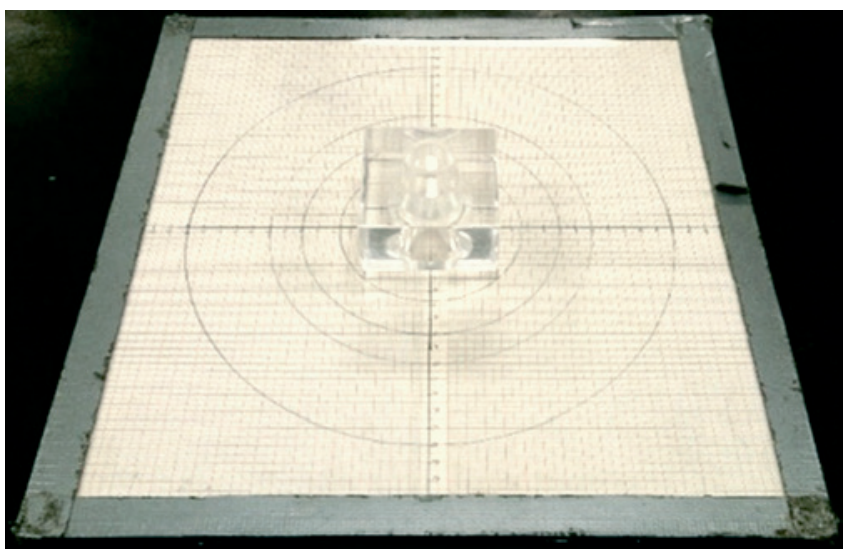

Figure 3.3

Acrylic mini-slump cone
Room temperature was monitored to be around $23 \pm 2^{\circ} \mathrm{C}$.

\subsubsection{Mini-slump}

After mixing, cement pastes were inserted in a Kantro's mini-slump acrylic cone of $6 \mathrm{~cm}$ high, $4 \mathrm{~cm}$ diameter smaller base and $2 \mathrm{~cm}$ diameter bigger base (Figure 3.3). Five strokes with a glass stirring rod to avoid the formation of air bubbles within the cone, and the excess of paste on the top was removed. The mold is lifted rapidly and the spreading recorded.

\subsubsection{Rotational rheometry}

Rotational Rheometry testing were performed in a Haake MARS 60 (Thermo Scientific), with parallel plate geometry of $25 \mathrm{~mm}$ diameter. The testing programed was conducted with shear rate from 0 to 50 $\mathrm{s}^{-1}$ and to 0 again as illustrated in Figure 3.4. Temperature was set
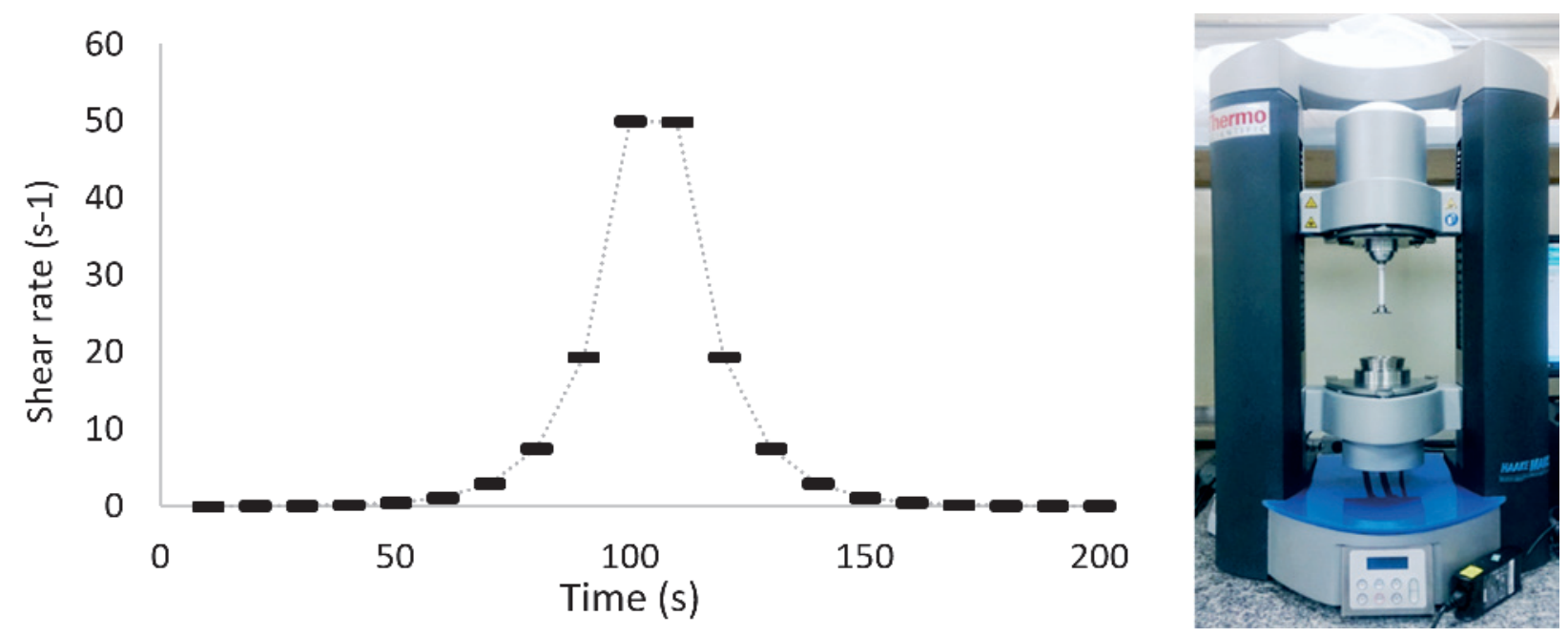

Figure 3.4

Rotational rheometry testing program (left); Haake MARS 60 paste rheometer (right)
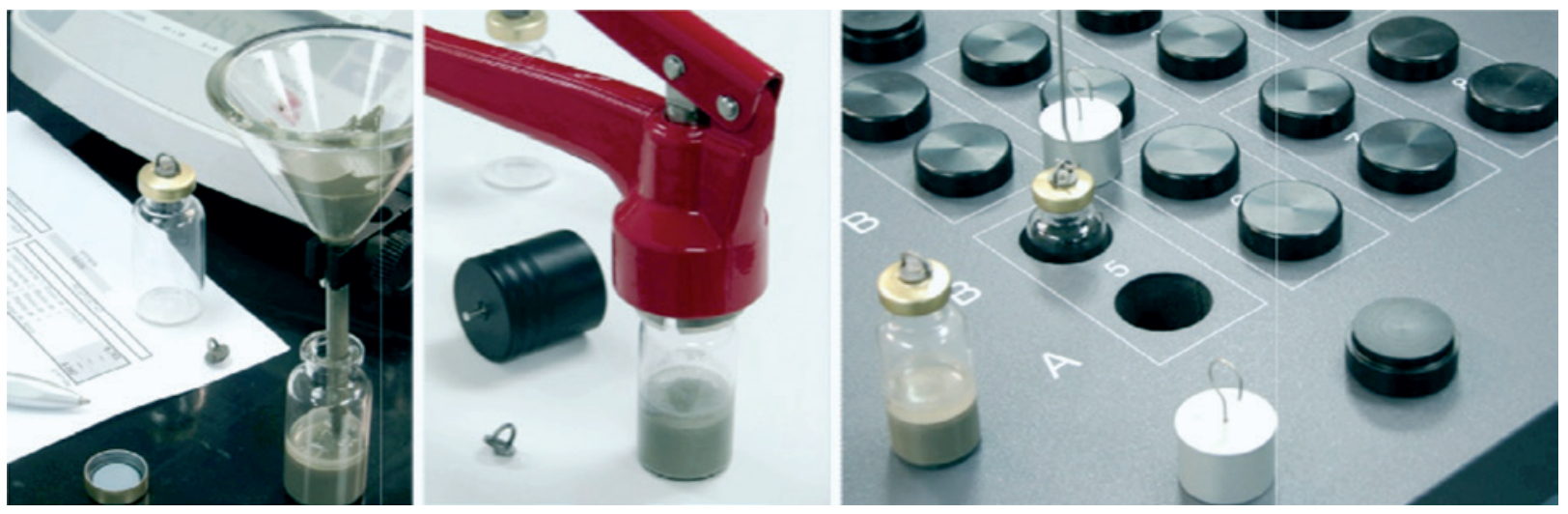

Figure 3.5

Isothermal calorimetry 


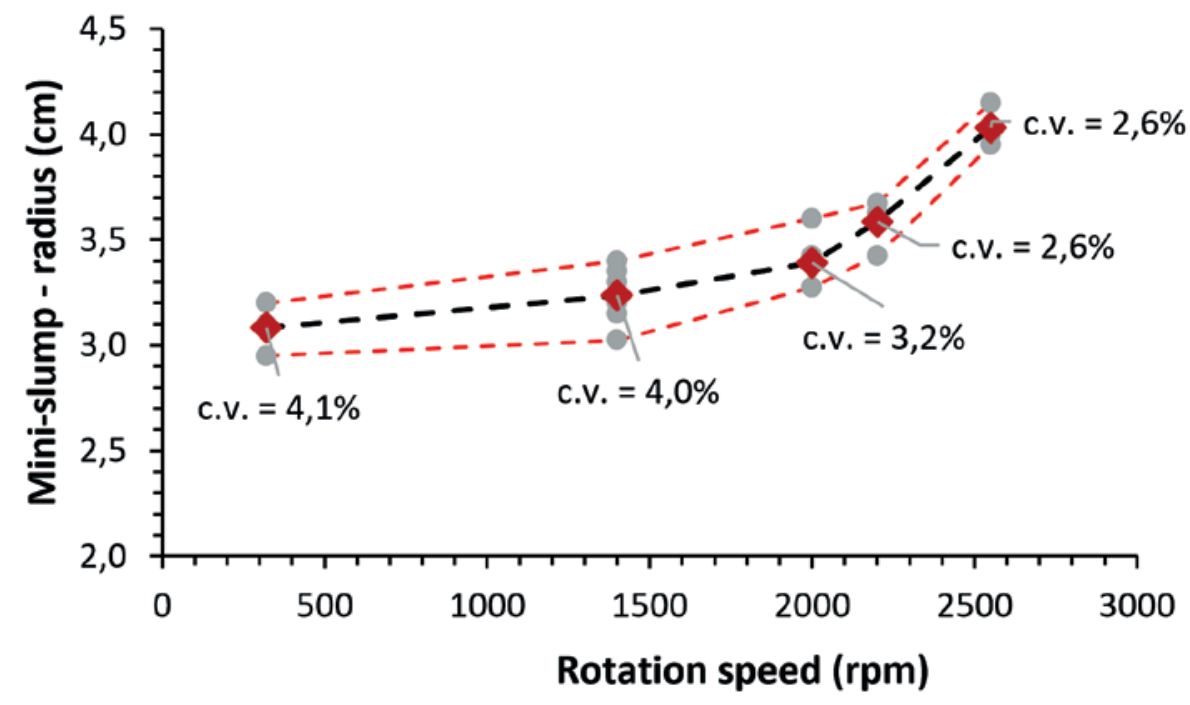

Figure 4.1

Average results (black line) and amplitudes (red lines) of mini-slump repetitions as a function of rotation speed (30 seconds of initial wetting and 90 seconds mixing)

to $23^{\circ} \mathrm{C}$. The result of the test are plots of shear strain ( $\sigma$ in Pa) or apparent viscosity ( $\eta$ em Pa.s) as a function of shear stress applied ( $\gamma$ em s-1).

\subsubsection{Isothermal calorimetry}

Hydration heat was measured by a TAM Air (TA Instruments) calorimeter (Figure 3.5 ) for 48 hours at constant temperature of $23^{\circ} \mathrm{C}$

\section{Results and discussion}

Initially the rotation speed setting was evaluated with mini-slump results for a fixed mixing time. Secondly, three different mixing times in three different rotation speeds considering the possibility of the testing to be influenced by hydration time. Thirdly, mini-slump cone tests were performed in parallel with Rotational Rheometry to analyze the possible correlation of yield stress and spread. Lastly, the effect of mixing on hydration heat was tested combining the shorter and longest mixing times with the smallest and highest rotation speed.

The statistical significance of the results was obtained by variance analysis and one sample t-student tests two by two considering two tailed distributions, unequal sample sizes and significance level of $5 \%$. The statistical analysis is presented for the first step of the study and only described for the following.

Table 4.1

Variance analysis of the results presented in Figure 4.1

\begin{tabular}{|c|c|c|c|c|c|c|}
\hline Source of variation & SS & df & MS & F & P-value & F crit \\
\hline Among groups & 1,77 & 4 & 0,44 & 25,56 & $4,69 E-06$ & 3,18 \\
\hline In the same group & 0,23 & 13 & 0,02 & - & - & - \\
\hline Total & 2,00 & 17 & - & - & - & - \\
\hline
\end{tabular}

\section{Table 4.2}

T-student tests matrices of results presented in Figure 4.1

\begin{tabular}{|c|c|c|c|c|c|}
\hline Groups & $\mathbf{3 2 0}$ & $\mathbf{1 4 0 0}$ & $\mathbf{2 0 0 0}$ & $\mathbf{2 2 0 0}$ & $\mathbf{2 5 0 0}$ \\
\hline 320 & - & $25,3 \%$ & $3,4 \%$ & $1,0 \%$ & $0,1 \%$ \\
\hline 1400 & $25,3 \%$ & - & $9,8 \%$ & $1,6 \%$ & $0,0 \%$ \\
\hline 2000 & $3,4 \%$ & $9,8 \%$ & - & $15,8 \%$ & $0,1 \%$ \\
\hline 2200 & $1,0 \%$ & $1,6 \%$ & $15,8 \%$ & - & $1,0 \%$ \\
\hline 2500 & $0,1 \%$ & $0,0 \%$ & $0,1 \%$ & $1,0 \%$ & - \\
\hline
\end{tabular}




\subsection{Influence of rotation speed on paste spread}

The first part of the tests consisted in producing pastes with 30 seconds initial wetting time and 90 seconds of rotation speed variation (320 to $2550 \mathrm{rpm}$ ). Four repetitions were conducted for each condition. The results presented in Figure 4.1 follow the expected trend. Parameters obtained from variance analysis and t-student test are presented on Table 4.1 and Table 4.2 respectively.

Variance analysis shows that there are distinct populations in the results ( $F>$ Fcrit). T-student test illustrate that rotations of 320 to 1400 1400 to 2000 and 2000 to 2200 do not reject the null hypothesis (>5\%). But other conditions are statistically different allowing the analysis of the influence of rotation speed on mini-slump spread.

The variation of results of the same mixing condition is smaller as shear time increases due to the increase in repetitiveness. The coefficient of variation goes from $4 \%$ in smaller rotations, to $2,6 \%$ in 2200 and $2550 \mathrm{rpm}$. Spreading increases as rotation speed increases indicating a reduction on yield stress (BANFILL, 2006; FERRARIS; OBLA; HILL, 2001; GAO; FOURIE, 2015; WILLIAMS; SAAK; JENNINGS, 1999; YANG; JENNINGS, 1995). This is expected due to the highest deagglomeration of particles result of the higher mixing energy (PANDOLFELLI et al., 2000).

\subsection{Impact of mixing time}

To evaluate not only mixing speed, but also the setting of different mixing times, the second evaluation performed in this work consisted in varying the mixing time in fixed rotation speeds $(320$, 1400 and $2550 \mathrm{rpm}$ ).

On the first group of mini-slump tests, spreading was recorded immediately after mixing (Figure 4.2) and analysis of variance showed that there were different populations. However, a possible inconsistency for the three rotation setting at 90 seconds of mixing was observed on all groups. After repetitions, temperature changes were discarded as a source of variation because the heat from mixing was irrelevant for all samples and room temperature was controlled. So, this variation may be related to initial hydration reactions.

Following, the hydration time (time after the first contact with water) was fixed on the second group of tests in 340 seconds. To reduce re-agglomeration effect during waiting time, pastes were subjected to remixing of 10 seconds prior to testing. This time was revealed sufficient in exploratory testing. Results are presented in Figure 4.3.

Analysis of variance proved that there are statistically different groups within the tests. T-student tests show that mixtures at $320 \mathrm{rpm}$ are the same for the three mixing times (60, 90 and 180 seconds). For $1400 \mathrm{rpm}$ the samples of first two mixing times are statistically the same. Lastly mixtures at $2550 \mathrm{rpm}$, all groups of three mixing times are distinct. At all mixing speeds, the last two set of mixing times (210 and 300 seconds) do not presented results with statistical difference. Moreover, results performed in the same hydration time do not display the inconsistency seen before at 90 seconds of mixing time. In this case is more evident the trend of bigger spread as mixing time increases specially at $2550 \mathrm{rpm}$. After this time, the longest mixture did not produce results of considerable spread increase. Therefore, the biggest spreading as obtained by a mixture of 210 seconds at $2550 \mathrm{rpm}$.

Comparing the results two by two in the same mixing conditions and different testing time, it is shown that cement pastes are different with exception of samples mixed for 300 seconds and at $320 \mathrm{rpm}$ for 60 seconds. The last one presented very small spread results. These results indicate that hydration time impacted on the cement pastes rheological behavior.

\section{4,3 Rotational rheometry}

To verify if there is a correlation between mini-slump and yield stress measured by Rotational Rheometry, tests were conducted

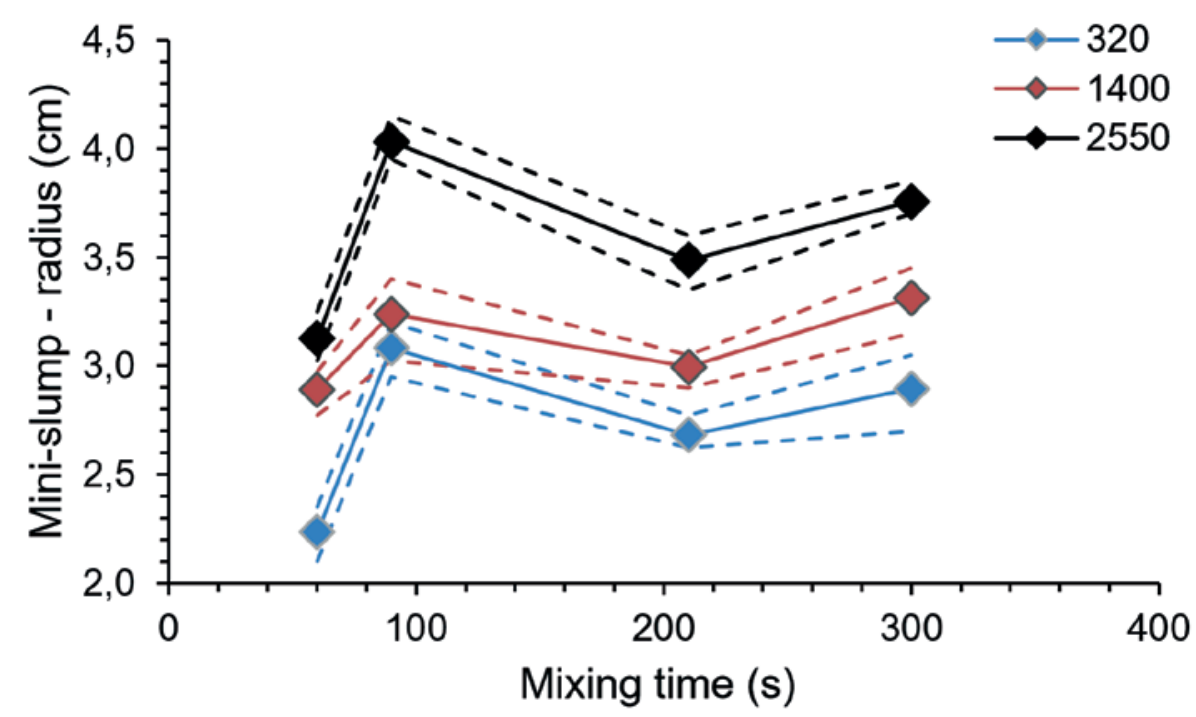

Figure 4.2

Results of mini-slump spread with different mixing times in different rotation speeds.

Dashed lines represent amplitude 


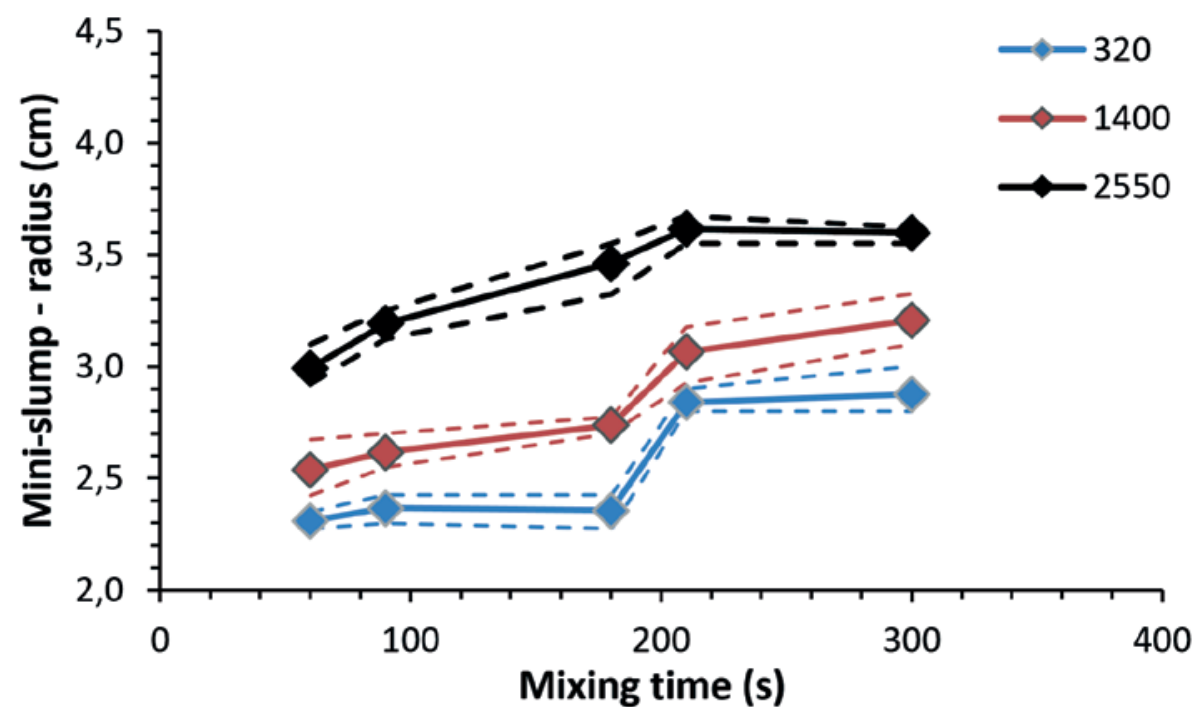

Figure 4.3

Results from mini-slump with different rotation speeds (testing performed after 340 seconds of hydration time with 10 seconds of remixing before testing). Dashed lines represent the amplitude of results

in pastes mixed at $1400 \mathrm{rpm}$ and $2500 \mathrm{rpm}$ for 210 and $300 \mathrm{sec}-$ onds. Samples were tested immediately after mixing and $340 \mathrm{sec}-$ onds from initial contact with water preceded by 10 seconds remixing time (same procedures used before).

Figure 4.4 illustrates typical results obtained from Rotational Rheometry which measures the necessary strain for each shear rate. In this case, pastes were accelerated from absolute resting to $50 \mathrm{~s}^{-1}$ and back to resting. Yield stress is obtained as the point with $1 \mathrm{~s}^{-1}$ shear rate (smallest with still good precision) on deceleration step. Results of yield stress as a function of rotation speed are presented in Figure 4.5. Apparently, the higher the rotation speed, the smaller are the yield stress results. It can also be observed that increasing mixing to $2550 \mathrm{rpm}$ has little impact on yield stress that remains very low. In this rotation speed, it was not possible to notice the effect of re-agglomeration after waiting time. The effect of mixing in apparent viscosity was relatively small. Even though only one test was performed for each mixing condition, the conclusions match with the ones presented before.

As reported by references (GAO; FOURIE, 2015), there is a fair correlation between mini-slump spread and yield stress obtained by Rotational Rheometry (Figure 4.6). On the other hand, Rotational Rheometry is much more sensible test than mini-slump: while yield stress varies between $\sim 0,5$ and $6 \mathrm{~Pa}$ (12 times), minislump varies from 3 to $4 \mathrm{~cm}$ (1,3 times). There was not a correlation between spread and apparent viscosity. The estimation of viscosity requires the measurement of time to flow during testing.

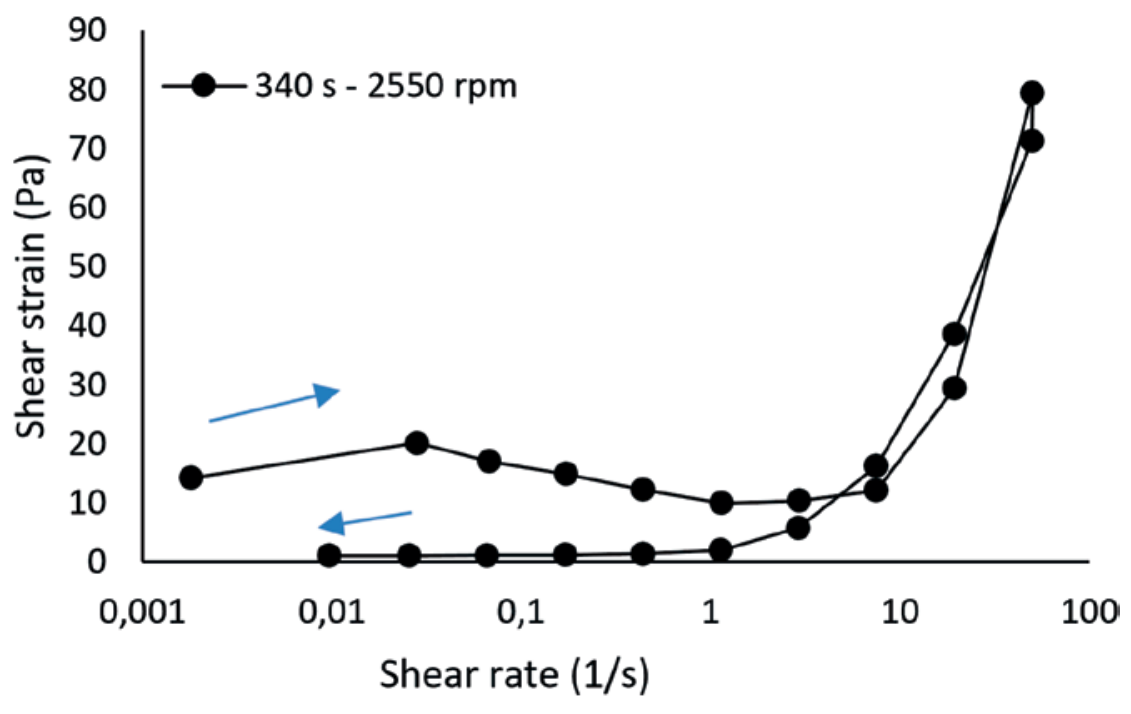

Figure 4.4

Typical result obtained from rotational rheometry testing 


\section{Figure 4.5}

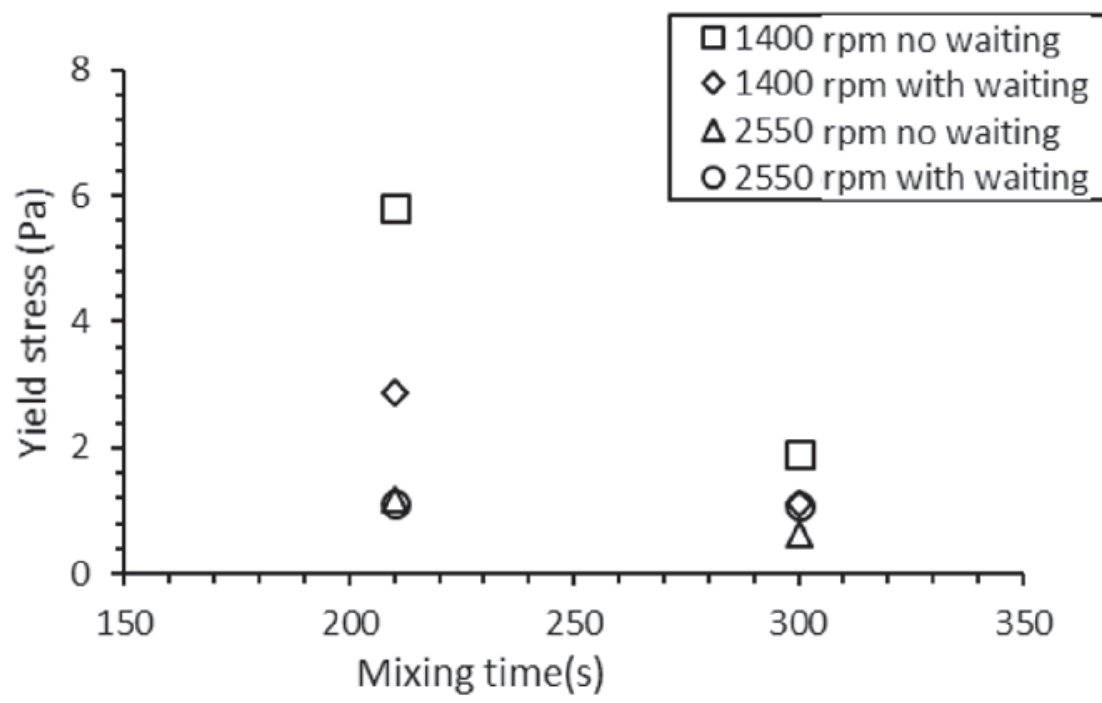

Yield stress as a function of mixing time for rotation speeds of 1400 and $2550 \mathrm{rpm}$ on testing performed immediately after mixing and after 340 seconds of hydration tim

\subsection{Influence of mixing on hydration kinetics}

References point that an increase in mixing induces a fastest hydration kinetics (BERODIER; SCRIVENER, 2015; JUILLAND et al., 2012; TAKAHASHI; BIER; WESTPHAL, 2011). This kinetics can be measured by isothermal calorimetry through heat liberation $(\mathrm{J} / \mathrm{s})$ during acceleration period. This impacts not only on initial strength, but also on the microstructure development of the cementitious material (YANG; JENNINGS, 1995).

Hydration heat was evaluated for cement pastes mixed for 60 and 340 seconds at 320 and $2550 \mathrm{rpm}$, conditions considered as borders of others so their variation would contain the others.

Figure 4.7 shows that rotation speed during mixing has influence on hydration kinetics while time of mixing does not. Mixing at 2550 rpm has more energy applied than at $320 \mathrm{rpm}$. Time of mixing impacts on the probability of chocks which, in the same mixing energy, to not change heat of hydration. These results agree with the ones found on references (BERODIER; SCRIVENER, 2015; JUILLAND et al., 2012; TAKAHASHI; BIER; WESTPHAL, 2011).

Setting time determined by isothermal calorimetry (ASTM C1679) reduced from $460 \mathrm{~min}$ (320 rpm) to $400 \mathrm{~min}$ (2550 rpm).

Not only hydration profile, but cumulated heat was also altered. The total heat measured after 48 hours was of 220 and $210 \mathrm{~J} / \mathrm{g}$ for samples mixed at $320 \mathrm{rpm}$ for 60 and 340 seconds respectively. But at $2550 \mathrm{rpm}$ the total heat increased to 240 and $235 \mathrm{~J} / \mathrm{g}$. Although there seems to be a slight difference in samples mixed

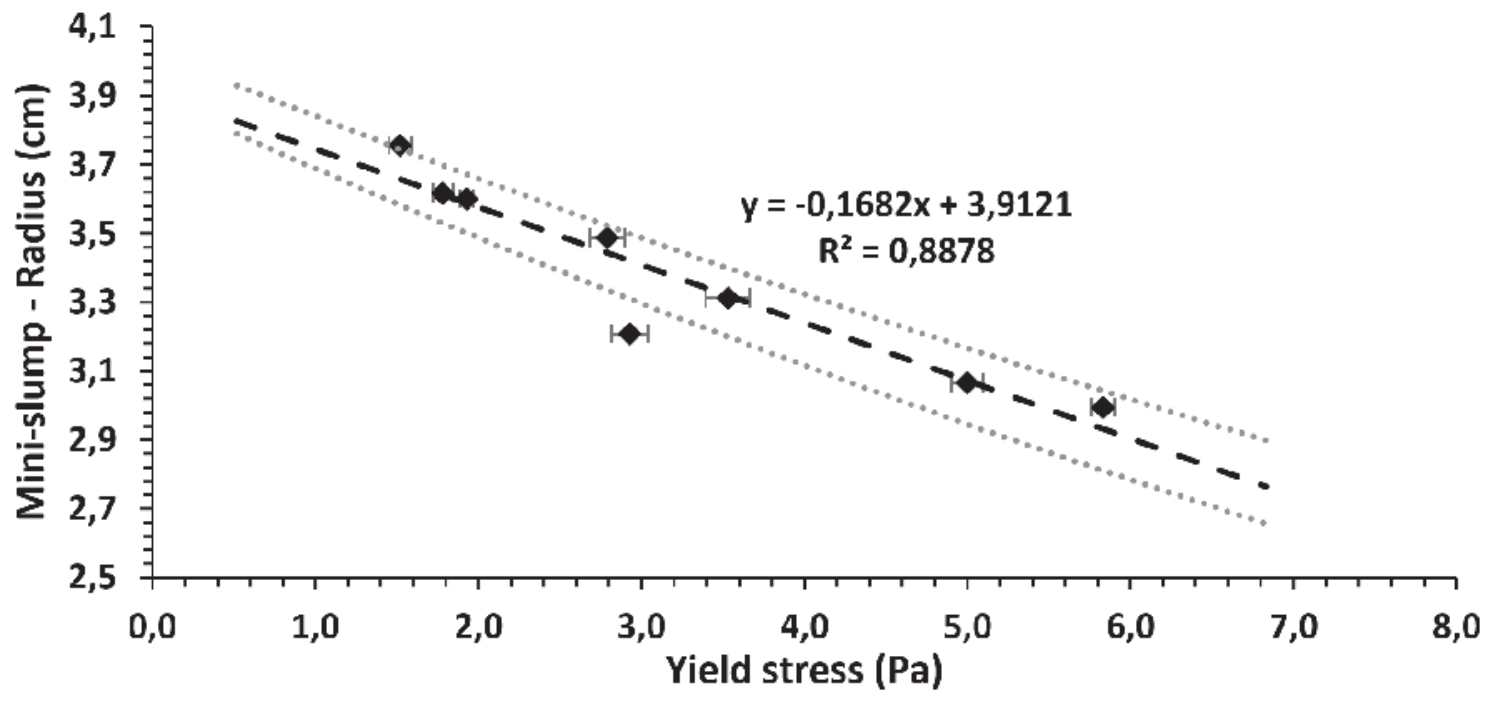

Figure 4.6

Mini-slump spread as a function of yield stress ( $\mathrm{Pa}$ ) obtained by rotational rheometry 


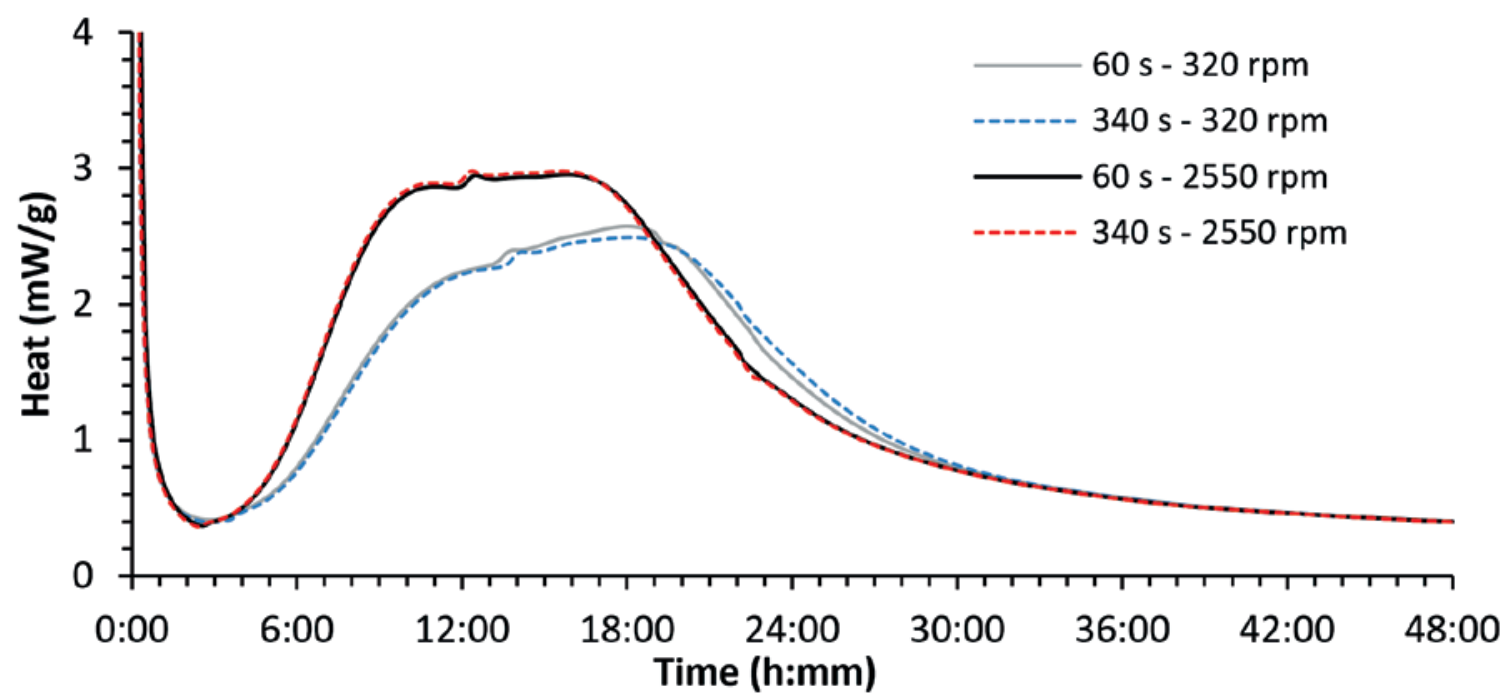

Figure 4.7

Hydration heat curves for mixing conditions $\left(23^{\circ} \mathrm{C}\right.$ isothermal)

in the same speed, produced heat increases as rotation speed increases. According to the references this is a result of the higher mixing energy that contributes to a higher reactivity due to shearing of particles (BERODIER; SCRIVENER, 2015).

\section{Conclusions}

Mixing energy, as presented in this study as time of mixing and rotation speed, furthermore the time following initial contact with water and testing time exerted relevant influence on results of minislump spread.

At higher mixing speeds that provide higher kinetic energy to particles and increase the chance of chocks that deagglomerate solution, results in general had smaller variation.

Mini-slump revealed to be a low cost tool, simple and sensitive to record changes on yield stress, an important parameter for rheological behavior evaluation. However, there is no information related to paste behavior under different shear rates due to the fact that mini-slump is a single point test.

Mixing influenced hydration heat as well: higher rotation speeds increased acceleration period rate. In practice, this effect will have major impact on initial strengths. On testing configuration, the most adequate mixing setting was the one of higher rotation speed, $2550 \mathrm{rpm}$, at 210 seconds of mixing time. It is probable that even higher mixing speeds, possible with other equipment, continue to drop results variability.

\section{References}

[1] AMERICAN SOCIETY FOR TESTING AND MATERIALS. ASTM C109: Standard Test Method for Compressive Strength of Hydraulic Cement Mortars (Using 2-in. or [50$\mathrm{mm}$ ] Cube Specimens). ASTM International, 2016.

[2] AMERICAN SOCIETY FOR TESTING AND MATERIALS. ASTM C1679: Standard Practice for Measuring Hydration
Kinetics of Hydraulic Cementitious Mixtures Using Isothermal Calorimetry. ASTM International, 2014.

[3] ASSOCIAÇÃO BRASILEIRA DE NORMAS TÉCNICAS. NBR 7215:1996 Versão corrigida 1997 - Cimento Portland Determinação da resistência à compressão. Rio de Janeiro, 1997. 8p

[4] ASSOCIAÇÃO BRASILEIRA DE NORMAS TÉCNICAS. NBR 11578:1991 Versão corrigida 1997 - Cimento Portland Composto - Especificação. Rio de Janeiro, 1997. 8p

[5] BANFILL, P. F. G. Rheology Of Fresh Cement And Concrete. In: Rheology Reviews 2006. London: The British Society of Rheology, 2006. p. 61-130.

[6] BERODIER, E.; SCRIVENER, K. L. Filler effect at early hydration. ICCC, International congress on the Chemistry of Cement, 2015.

[7] DAMINELI, B. L. et al. Viscosity prediction of cement-filler suspensions using interference model: A route for binder efficiency enhancement. Cement and Concrete Research, v. 84, p. 8-19, jun. 2016.

[8] DOLLIMORE, D.; MANGABHAI, R. J. Effect of mixing time on heat evolution pattern of cement pastes. Thermochimica Acta, v. 85, p. 223-226, 1 abr. 1985.

[9] EUROPEAN COMMITTEE FOR STANDARDIZATION. EN 197-1: Cement - Part 1: Composition, specifications and conformity criteria for common cements. Brussels, 2012.

[10] FERRARIS, C. F.; OBLA, K. H.; HILL, R. The influence of mineral admixtures on the rheology of cement paste and concrete. Cement and Concrete Research, v. 31, n. 2, p. 245-255, fev. 2001.

[11] GAO, J.; FOURIE, A. Spread is better: An investigation of the mini-slump test. Minerals Engineering, v. 71, p. 120-132, fev. 2015.

[12] JUILLAND, P. et al. Effect of mixing on the early hydration of alite and OPC systems. Cement and Concrete Research, v. 42, n. 9, p. 1175-1188, set. 2012. 
[13] PANDOLFELLI, V. C. et al. Dispersão e empacotamento de partículas - princípios e aplicações em processamento cerâmico. São Paulo: Fazendo Arte, 2000.

[14] ROMANO, R. C. O. et al. Impacto do tipo de misturador e do tempo de mistura nas propriedades de argamassas industrializadas. Ambiente Construído, Porto Alegre, v. 9, n. 4, p. 109-118, 2009.

[15] SANYTSKY, M.; KROPYVNYTSKA, T.; RUSYN, B. Sustainable green engineered composites containing ultrafine supplementary cementitious materials. ICCC, International congress on the Chemistry of Cement, 2015.

[16] TAKAHASHI, K.; BIER, T. A.; WESTPHAL, T. Effects of mixing energy on technological properties and hydration kinetics of grouting mortars. Cement and Concrete Research, v. 41, n. 11, p. 1167-1176, nov. 2011.

[17] WEDDING, P.; KANTRO, D. Influence of Water-Reducing Admixtures on Properties of Cement Paste-A Miniature Slump Test. Cement, Concrete and Aggregates, v. 2, n. 2, p. 95, 1980.

[18] WILLIAMS, D. A.; SAAK, A. W.; JENNINGS, H. M. The influence of mixing on the rheology of fresh cement paste. Cement and Concrete Research, v. 29, n. 9, p. 1491-1496, set. 1999.

[19] YANG, M.; JENNINGS, H. M. Influences of mixing methods on the microstructure and rheological behavior of cement paste. Advanced Cement Based Materials, v. 2, n. 2, p. 70 78, mar. 1995. 